\title{
Identification of Vietnamese Paphiopedilum Species Using Vegetative Morphology
}

Huyen-Trang Vu ${ }^{1^{*}}$, My-Huyen Bui ${ }^{1}$, Quoc-Luan Vu${ }^{2}$, Thanh-Diem Nguyen ${ }^{1}$,
Hop Tran ${ }^{3}$, Huu-Trung Khuat ${ }^{4}$ and Ly Le ${ }^{5}$

${ }^{1}$ Faculty of Biotechnology, Nguyen Tat Thanh University, Ho Chi Minh City 700000, Vietnam.

${ }^{2}$ Tay Nguyen Institute for Scientific Research, Vietnam Academy of Science and Technology, Lam Dong Province 670000, Vietnam.

${ }^{3}$ University of Natural Science, Ho Chi Minh City 700000, Vietnam. ${ }^{4}$ Agricultural Genetics Institute, Pham Van Dong Street, Hanoi 100000, Vietnam.

${ }^{5}$ Faculty of Biotechnology, International University - Vietnam National University, Ho Chi Minh City 700000, Vietnam.

\begin{abstract}
Authors' contributions
This work was carried out in collaboration among all authors. Author HTV designed the study, performed the statistical analysis and wrote the first draft of the manuscript. Authors MHB, QLV, TDN, HT, HTK and LL managed the analyses of the study. Author HTV managed the literature searches. All authors read and approved the final manuscript.
\end{abstract}
Article Information
DOI: $10.9734 / A R R B / 2019 / v 34 i 1301445$
Editor(s):
ogy, University of Perugia, Perugia, Italy.
(1) Dr. Paola Angelini, Department of Applied Biology, University of Perugia, Perugia, Italy.
Reviewers:
(1) Oguh Collins Egwu, University of Nigeria, Nigeria.
(2) Fábio Henrique Portella Corrêa de Oliveira Botany, Universidade Federal Rural de Pernambuco, Brazil.
(3) Maliwan Nakkuntod, Naresuan University, Thailand.
Complete Peer review History: http://www.sdiarticle4.com/review-history/53724

Original Research Article

Received 30 October 2019

Accepted 01 January 2020

Published 10 January 2020

\begin{abstract}
Background: Discrimination of Paphiopedilum species using floral morphology has been used effectively and commonly due to distinct features of their reproductive parts. Most classification references also focus on description of flower morphology and structure. Nevertheless species preservation meets great problems when illegal trading plants are mostly at non-flowered or plantlet stages. Molecular approaches have been applied and obtained highly precise results but spent time and could not rate $100 \%$ of resolution over the genus. Thus, quickly identification using only vegetative characteristics would be an efficient support for other distinguishing methods and a remarkable contribution to the detection and prevention of Paphiopedilum ilicit sales.
\end{abstract}




\begin{abstract}
Aims: In this research we aimed to describe in details leaf features of Paphiopedilum species in Vietnam serving for quick and easy discriminating species without flower present or laboratory techniques.

Study Design: Observed variables based on qualitative features of leaf shape, color, vein feature, thickness, toughness and quantitative features of leaf size were saved and organized using Microsoft Excel 2010.

Place and Duration of Study: Tay Nguyen Institute for Scientific Research, Agricultural Genetics Institute, between November 2018 and November 2019.

Methodology: We minutely analyzed the leaf morphology of nineteen species and two variants which belongs to Vietnamese Paphiopedilum population in an order manner from parameters that easiest to be realized to the less clearly traits for the most efficient recognition even to the one who is not botanist.

Results: 16 out of 20 species were identified using leaf morphology. This rate was up to $100 \%$ when combining morphological and molecular methods without the present of their flowers. An artificial key to genus Paphiopedilum using the vegetative details was first time established.

Conclusion: Leaf morphology can be effectively used as the first step for identifying Paphiopedilum species. Our results provided useful tool in severally or in combination with molecular methods in biodiversity and commercial management of these valuable species.
\end{abstract}

Keywords: Vegetative morphology; morphology identification; Paphiopedilum; species conservation; artificial key; biodiversity management.

\section{INTRODUCTION}

Morphology identification is a crucial technique serving for many applications. Kasutjianingati and Firgiyanto [1] described the morphological characteristics of endangered Indonesian Vanda orchids for conservation of germplasm and breeding programs [1]. Analysis and comparison of the morphology of fruits and pollen provided information in the study of pollination process, while increasing the pollination efficiency of some orchids [2-4]. Morphological analysis of functional organs is expected to respond to environmental conditions. In particular, the root morphology reflects the resistance and respond to environmental conditions [5]. Based on the floral morphological relationship, 24 variation of the genus Himantoglossum was determined [6]. The morphology plays an important role in determining the relationship between species and supporting the study of the growth and reproduction process to help conserve rare orchid species. However most studies focused on flower morphology and structure as main criteria for species identification [6-9]. The problem is, in practical, most illegal trading plants are immature or at none-flowered stages. As a result, there are misidentification among rare and common species.

Paphiopedilum is a rare orchid group interested by many people and researchers because of its beauty and high economic value. Their flowers have a special shape which look like colorful lovely slippers [10]. More than 80 Paphiopedilum species worldwide have been found from nature and through cross-breeding $[11,12]$. Vietnam is one of the countries with high density and biodiversity of more than 20 Paphiopedilum species.

Traditional identification of Paphiopedilum based on flower morphology is the most popular and effective method even among closely related species in the same genus because their flowers have distinct characteristics from colors (red, pink, yellow, purple, white, blue, veined, red spots ...), to shape (Oval petals or oblong, wing edges have twisted or wavy, special shape of lips, etc.) [12-14]. Leonid Averyanov and his colleagues evaluated biodiversity of this genus in 2004 and reported that Vietnam flora are much abundant and interesting. This project has contributed to the understanding of diversity and threats of these natural resources in Vietnam [11]. In the above studies vegetative features were presented basically without detailed comparisons among species and could not be used as independent identification criteria. However, most of plant life are at the stage of non-flower. This is a limitation for identification and protection of these species from illegal trade. From 2006 Paphiopedilum species were listed in group of organisms that are strict banned from exploitation and commercial use in Vietnam. Nevertheless, in recent consecutive years up to $99 \%$ of these species were reported to be 
extinctly endangered due to the reduce of habitat and the overcollection. So, the need of identification individuals based on their vegetative organs significantly contribute to the prevention of the illegal trade of these rare species.

According to our observation, some detailed leaf characters could be utilize as effective tools for quickly identification of Paphiopedilum taxa even to species that similar in morphology and closed in relationship. This study aimed to construct detailed description data of Vietnam Paphiopedilum species based on vegetative morphology, which was arranged and summarized into an artificial classification key for simple identification of this genus.

\section{MATERIALS AND METHODS}

Ninety-four Paphiopedilum plants belonging to 20 original species and 2 varieties of genus Paphiopedilum in Vietnam were obtained from the gene conservation collections of Tay Nguyen Institute for Scientific Research, Lam Dong, South Vietnam and Agricultural Genetics Institute, Ha Noi, North Vietnam. Those samples have been collected from different geographic areas and provinces of Vietnam which were preliminary identified by both floral characteristics [11] and molecular barcodes of ITS and matK sequences from our previous study [15].

All samples were taken photographs and recorded measurements serving for intra- and inter-specific morphological analysis. The distinguishing vegetative characters were analyzed focus on leaf morphology based on following criteria: blade/lamina shape (oblong, elliptic), size, leaf tip, midrib, vein, small netted vein, leaf margin, leaf base, color upperside, color underside, surface (rough-glossy/smooth), cilia, leaf thickness, leaf toughness, leaf direction. Each characteristic was observed on studied samples and pictures, referenced by monograph book of Paphiopedilum [10,11] for more reliable. Studied species were not described in separate but in comparison with their other sisters. The order of description started from most to fewer notable characteristics which could stand out the differences among species samples. Observed variables based on qualitative features of leaf shape, color, vein feature, thickness, toughness and quantitative features of leaf size were saved and organized using Microsoft Excel 2010.

\section{RESULTS AND DISCUSSION}

\subsection{General Characteristics of Vegetative Organs of Paphiopedilum Genus}

Paphiopedilum species are herbal plants with extremely short rhizomes and stems except $P$. malipoense and $P$. micranthum with linked multirhizomes into underground nets. There are 3-7 distichous leaves which are elliptic, oblong or obovate. Leaf apex is round or acute and often asymmetrically bilobate or trilobate. Leaf base is conduplicate into V-shaped, enclosing around stem. Blade is plain green pattern or tessellated with dark and pale green above. This mosaic pattern is very typical for many Paphiopedilum orchids. These mosaic spots are thought to be due to the uneven distribution of chlorophylls on the leaf surface resulting in alternate light and dark spots [12]. Some species spotted with purple spots at base or throughout the lower surface. The characteristics and density of the blue mosaic spots on the upper and lower surfaces of leaves are specific to species when observing in details.

\subsection{Discrimination of Paphiopedilum Species Using Vegetative Polymorphism}

Amongst vegetative features, the first trait that easiest to realize was the leaf coloration on the upper surface. According to this criterion, Paphiopedilum species were divided into two distinct groups: tessellated group with darker green on and between veins and one group with uniformly green patterning. The tessellated group included 9 species $P$. appletonianum, $P$. armeniacum, $P$. callosum, $P$. concolor, $P$. delenatii, $P$. malipoense, $P$. micranthum, $P$. purpuratum and $P$. vietnamense in which the two survived variants $P$. malipoense var. malipoense và $P$. malipoense var. jackii were collected. We called this Group 1. The uniformly green group included 10 species $P$. coccianum, $P$. emersonii, $P$. gratrixianum, $P$. hangianum, $P$. helenae, $P$. henryanum, $P$. hirsutissimum, $P$. dianthum, $P$. tranlienianum and $P$. villosum. These were called Group 2. For more easy to follow, a summary of the identification process was shown in Fig. 6 .

\subsubsection{Group 1: Distinguish species in the group of tessellated leaves upperside}

To this group, the purple marks underside of the leaves were the next observation. There are clearly purple to red-purple spots throughout the 
lower surface of 6 species $P$. armeniacum, $P$. concolor (although such markings may be dense or reduced in various plants of this species), $P$. delenatii, $P$. micranthum, $P$. malipoense and $P$. vietnamense - Group 1A (Fig. 1). On the contrary 4 species $P$. appletonianum, $P$. dalatense, $P$. callosum and $P$. purpuratum were figured out with solid pale green all over the lowerside or just few purple marks at the lowerside toward base - Group 1B (Fig. 2).

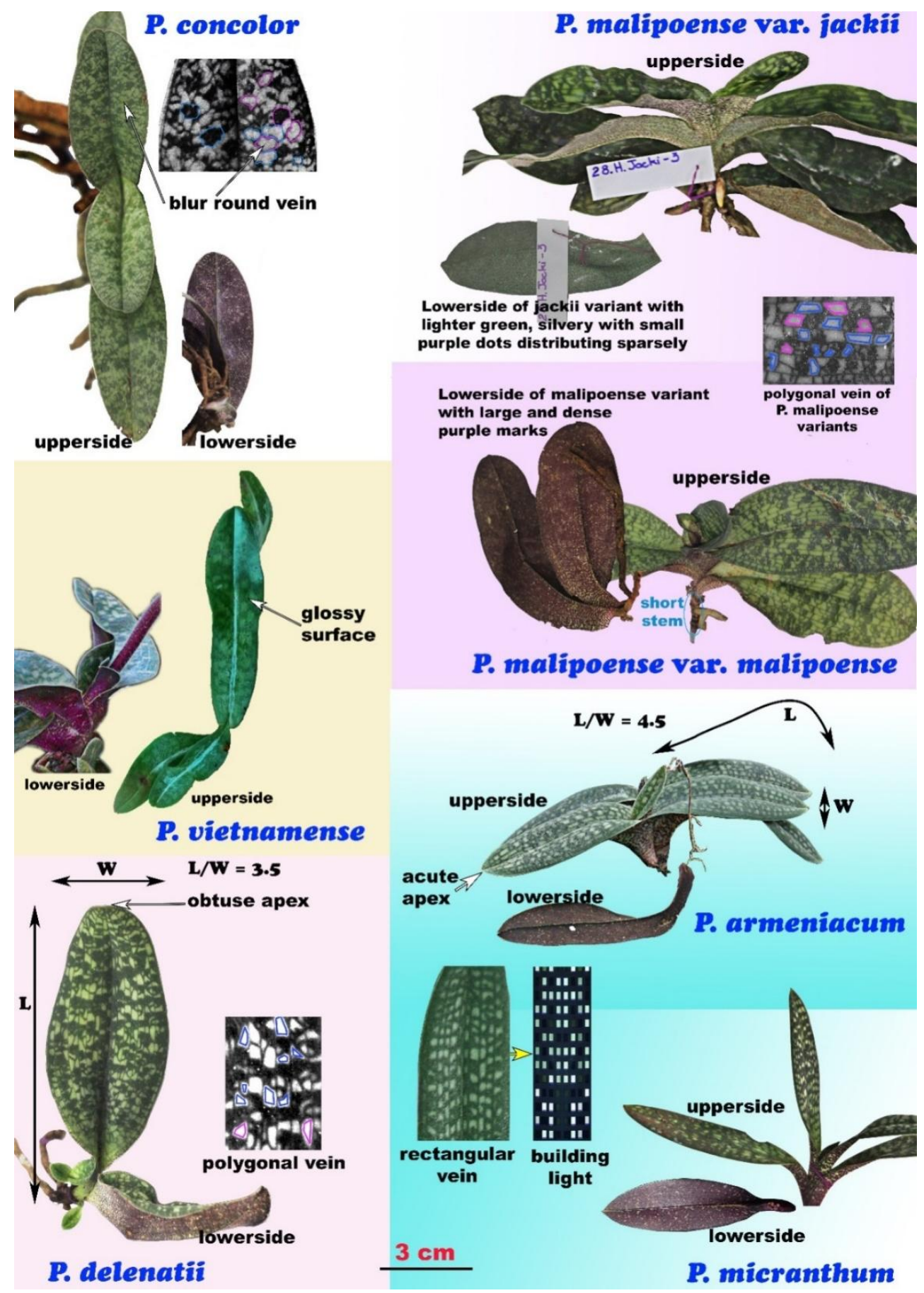

Fig. 1. Group 1A-Paphiopedilum species with tessellated leaves upperside and purple marks lowerside 


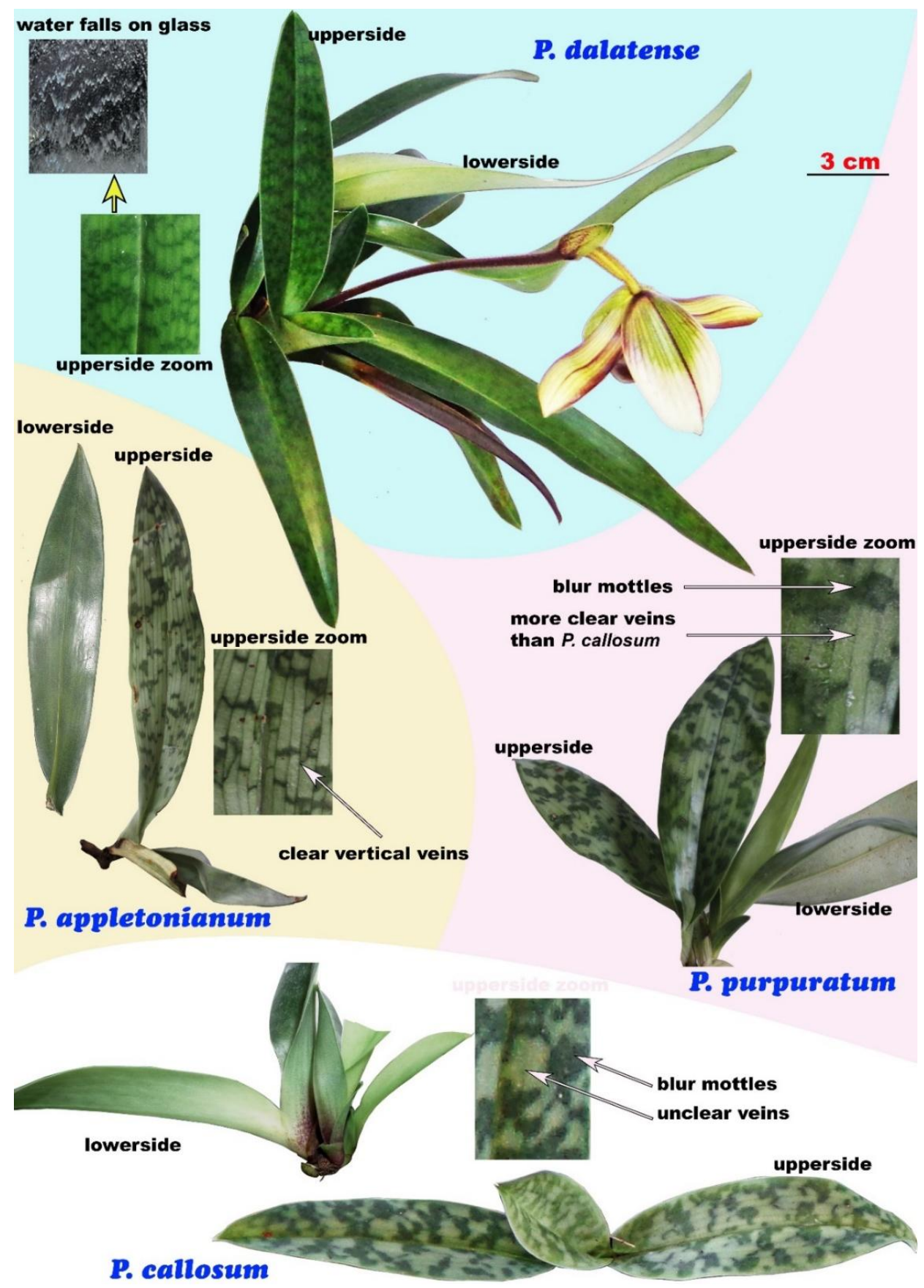

Fig. 2. Group 1B - Paphiopedilum species with marbled marks above, simple green below

Group 1A: The Paphiopedilum concolor was separated from other 5 species based on the distinguished mottle characteristics on the adaxial surface of the leaves. Meanwhile the linear veins are well defined in the others generating the square-form or rectangular-form or polygon-form of dark green mottles, $P$. concolor holds the serrated round-form which is less clearly marked and looks like mottles on the panther fur. Although the shape and color may vary under different condition, the general tendency can be observed is distinctly closed zigzag lines creating heavy green round blobs (Fig. 1). 
Group 1A: The $P$. vietnamense is special with a smooth and glossy surface on both sides, which we can deeply feel when touching or observing under the light. Because of the glossy surface, the leaf color tends to silver green. On the contrary, the two variants of $P$. malipoense are extra rough on both sides of the leaves, create the feel of many tiny granules covering the leaves. Furthermore, the lamina of these both variants are broad, coriaceous and thin then their leaf margins are plicate while it is linear for $P$. vietnamense, $P$. armeniacum, $P$. delenatii and $P$. micranthum (Fig. 1). Although belonging to the same species, there are still features to distinguish the two variants $P$. malipoense var. malipoense and $P$. malipoense var. jackii based on the purple spots underside again. The leaf background is lighter green, silvery with small purple dots distributing sparsely below in variant jackii. Meanwhile the intension of purple marks in variant malipoense is larger and much more than the former one leading to the dense overlapping most of the undersurface.

Group 1A: For 3 species $P$. armeniacum, $P$. delenatii and $P$. micranthum in term of leaf shape, they are all similar. In term of leaf size, the mature $P$. delenatii are often $8-14 \mathrm{~cm}$ long while the two $P$. armeniacum và $P$. micranthum species are both about $6.5-10.5 \mathrm{~cm}$ (Table 1 ). However, this criterion is a relative property which is difficult to observed and cannot apply to plantlets. Thus we had to combine several measurements concurrently to achieve identification target. Firstly the ratio between leaf length and width, which would not be affected by plant age, were examined. The lamina of $P$. delenatii is broader, length/width ratio about 3.45 (the detailed size account was recorded in Table 1 ), thinner and lither than of $P$. armeniacum and $P$. micranthum, then express a slight waving. Meantime, the length/width ratio is notably higher, around $4.5-5$, for both remainders, which means it is more slender oblong in shape. Besides leaves of these 2 species are small, narrow, harder and thicker, then quite plain (Fig. 1 ). Secondly the leaf tips of $P$. armeniacum and $P$. micranthum are acute while it is obtuse in $P$. delenatii. Thirdly we relied on coloration and shape of mottles on the leaf upper surface. In $P$. delenatii, the tessellated marks make up equal or less than $50 \%$ the bodily surface gives the sense of dark green mottles on the pale green background. Their longitudinal veins are also not as even and tight as of $P$. armeniacum and $P$. micranthum. This forms various polygonal shape of mottles such as rectangular, square, pentagon, polygon. By contrast, $P$. armeniacum and $P$. micranthum with the dark color much more than the light color give the sense of the white mottles on the dark green background. The veinlets are parallel so mottle shape is quite even, rectangular along the midrib which make us imagine a series even light windows of a multi-store building, especially is easy to be recognized at the leaf tip (Fig. 1). We cannot find any feature to separate between $P$. armeniacum and $P$. micranthum as they are allied to each other from shape, coloring to size.

Group 1B: Next we identify the 4 species $P$. appletonianum, $P$. dalatense, $P$. callosum, $P$. purpuratum in the group of marbled marks above, simple green below. All of these species are slightly glossy, elliptic, acute towards tip. $P$. dalatense is a hybrid of $P$. callosum (Group 1) and $P$. villosum (Group 2). P. dalatense leaf has the background quite green hence the dark marks are blur on the upperside and create horizontal serrated veins look like pattern of water flushed on the glass wall (Fig. 2). $P$. appletonianum is distinguished by large area of pale green background causing clearly parallel veination and its rectangular tessellated mottles are sparsely dusting on the upperside. Due to the more dark background color, the veins in $P$. callosum and $P$. purpuratum are fairly inconspicuous (Fig. 2).

Group 1B: $P$. callosum resembles $P$. purpuratum in both leaf and stem morphology. The Vietnamese vernacular name of both species also express this similar in sculpturing patterns, $P$. callosum as the South Van and P. purpuratum as the North Van. Consequently it is hard to distinguish these two species. Some minutely details can be considered. $P$. callosum has thicker, plainer and more succulent leaves, their leaf sculpture is fainter. $P$. purpuratum has thinner, rougher leaves, their leaf growing tends to fall down, their vein color is lighter and clearer (Fig. 2). However these measurements are not strictly exact and can just apply in case we have both species samples at once to compare.

\subsubsection{Group 2 - Distinguish species in the group of uniformly plain green leaves upperside}

Among 10 species of this group, $P$. henryanum could be determined with a very particular bold white line along the leaf margin. We can sometimes see this line being white or yellow at other species however they are all much lighter and thinner (Fig. 3). 
Most of species in this group express fine purple spots towards the base beneath, which sometimes develop into dense purple area, except $P$. hirsutissimum individuals which have no this character. Particularly $P$. tranlienianum is also different with no spot but fine purple streaks instead. A minute trait can be used to realize $P$. tranlienianum is that their leaf base is wide opened instead of bundling up the stem (Fig. 3).
$P$. helenae is especially small in size. The mature plants are only $7-9 \mathrm{~cm}$ long with an average of $8.3 \mathrm{~cm}$ while the length of the other species rank from $15.9 \pm 2.26$ to $26.8 \pm 3.84 \mathrm{~cm}$. The leaf surface area (length multiplied by width) of $P$. helenae just $11.12 \pm 1.43 \mathrm{~cm}^{2}$ while the others are from $25.4 \pm 5.76$ to $98.02 \pm 8.92 \mathrm{~cm}^{2}$ (Table 1). For this reason $P$. helenae is named "Short Slipper orchid" in Vietnam (Fig. 3).

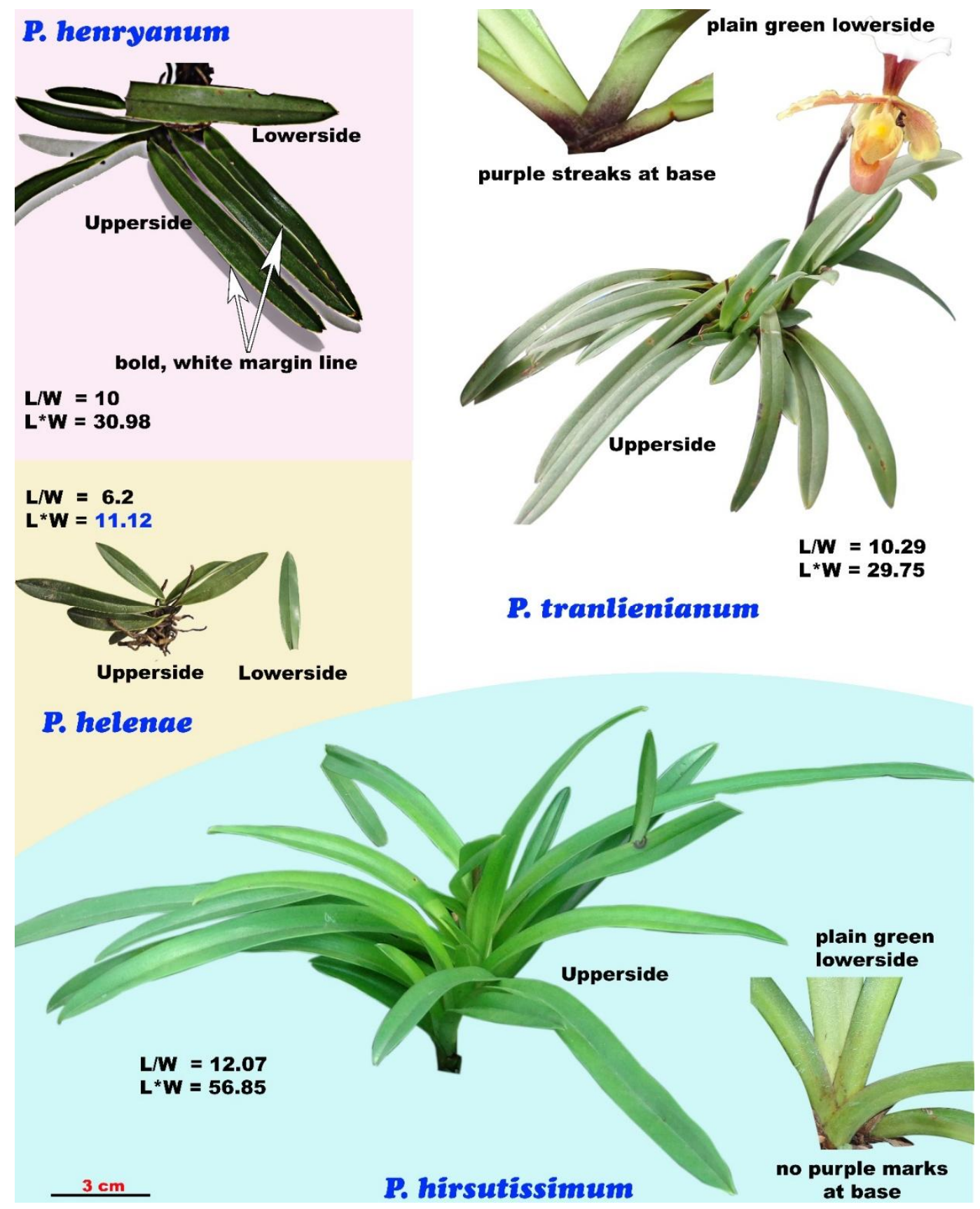

Fig. 3. Group $2-P$. henryanum, $P$. hirsutissimum, $P$. tranlienianum and $P$. helenae 


\section{Table 1. Leaf mesurements of analyzed species}

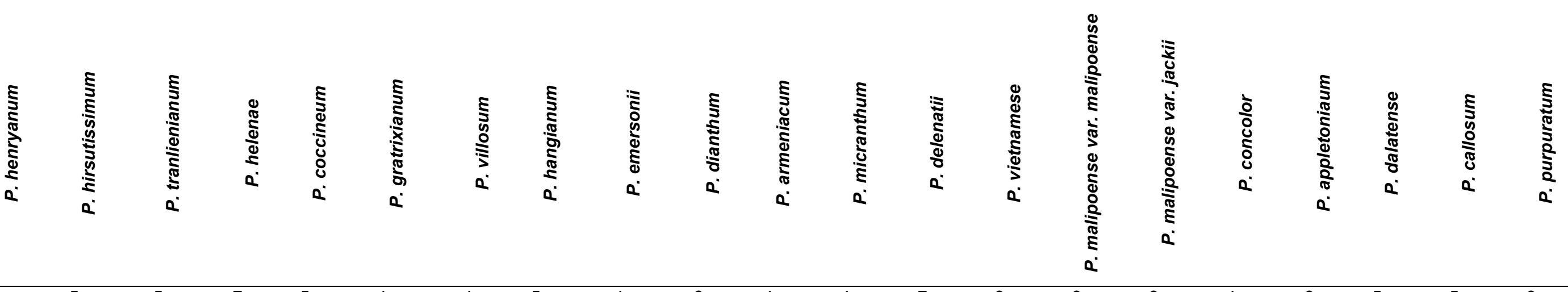

\begin{tabular}{|c|c|c|c|c|c|c|c|c|c|c|c|c|c|c|c|c|c|c|c|c|c|}
\hline $\begin{array}{l}\text { Number of } \\
\text { samples }\end{array}$ & 3 & 5 & 5 & 7 & 5 & 4 & 4 & 5 & 4 & 6 & 4 & 4 & 7 & 3 & 3 & 3 & 4 & 6 & 5 & 5 & 3 \\
\hline $\begin{array}{l}\text { Average } \\
\text { length } \\
(\mathrm{L})(\mathrm{cm})\end{array}$ & $\begin{array}{l}17.6 \\
\pm 4.19\end{array}$ & $\begin{array}{l}26.53 \\
\pm 4.74\end{array}$ & $\begin{array}{l}17.5 \\
\pm 2.68\end{array}$ & $\begin{array}{l}8.3 \\
\pm 0.77\end{array}$ & $\begin{array}{l}15.9 \\
\pm 2.26\end{array}$ & $\begin{array}{l}26.80 \\
\pm 3.84\end{array}$ & $\begin{array}{l}24.2 \\
\pm 4.19\end{array}$ & $\begin{array}{l}19.00 \\
\pm 3.1\end{array}$ & $\begin{array}{l}18.70 \\
\pm 4.86\end{array}$ & $\begin{array}{l}22.8 \\
\pm 1.38\end{array}$ & $\begin{array}{l}8.5 \\
\pm 1.61\end{array}$ & $\begin{array}{l}8.54 \\
\pm 1.59\end{array}$ & $\begin{array}{l}12.04 \\
\pm 2.59\end{array}$ & $\begin{array}{l}10.91 \\
\pm 4.47\end{array}$ & $\begin{array}{l}11.23 \\
\pm 1.77\end{array}$ & $\begin{array}{l}10.86 \\
\pm 1.04\end{array}$ & $\begin{array}{l}13.12 \\
\pm 2.89\end{array}$ & $\begin{array}{l}11.75 \\
\pm 2.2\end{array}$ & $\begin{array}{l}19.1 \\
\pm 3.40\end{array}$ & $\begin{array}{l}13.8 \\
\pm 2.15\end{array}$ & $\begin{array}{l}12.85 \\
\pm 0.85\end{array}$ \\
\hline $\begin{array}{l}\text { Average } \\
\text { width } \\
\text { (W) }(\mathrm{cm})\end{array}$ & $\begin{array}{l}1.76 \\
\pm 0.24\end{array}$ & $\begin{array}{l}1.77 \\
\pm 0.14\end{array}$ & $\begin{array}{l}1.7 \\
\pm 0.51\end{array}$ & $\begin{array}{l}1.34 \\
\pm 0.09\end{array}$ & $\begin{array}{l}1.59 \\
\pm 0.15\end{array}$ & $\begin{array}{l}2.52 \\
\pm 0.42\end{array}$ & $\begin{array}{l}2.17 \\
\pm 0.23\end{array}$ & $\begin{array}{l}4.3 \\
\pm 0.33\end{array}$ & $\begin{array}{l}3.90 \\
\pm 0.27\end{array}$ & $\begin{array}{l}4.3 \\
\pm 0.24\end{array}$ & $\begin{array}{l}1.9 \\
\pm 1.27\end{array}$ & $\begin{array}{l}2.06 \\
\pm 0.77\end{array}$ & $\begin{array}{l}3.48 \\
\pm 0.40\end{array}$ & $\begin{array}{l}3.42 \\
\pm 0.25\end{array}$ & $\begin{array}{l}4.03 \\
\pm 0.20\end{array}$ & $\begin{array}{l}3.57 \\
\pm 1.03\end{array}$ & $\begin{array}{l}3.26 \\
\pm 0.68\end{array}$ & $\begin{array}{l}2.22 \\
\pm 0.53\end{array}$ & $\begin{array}{l}2.84 \\
\pm 0.58\end{array}$ & $\begin{array}{l}3.06 \\
\pm 0.77\end{array}$ & $\begin{array}{l}3.29 \\
\pm 0.2\end{array}$ \\
\hline Ratio (L/W) & $\begin{array}{l}10.05 \\
\pm 2.31\end{array}$ & $\begin{array}{l}15.07 \\
\pm 3.01\end{array}$ & $\begin{array}{l}10.7 \\
\pm 2.26\end{array}$ & $\begin{array}{l}6.22 \\
\pm 0.62\end{array}$ & $\begin{array}{l}10.02 \\
\pm 0.98\end{array}$ & $\begin{array}{l}10.67 \\
\pm 0.52\end{array}$ & $\begin{array}{l}11.36 \\
\pm 3.10\end{array}$ & $\begin{array}{l}4.40 \\
\pm 0.54\end{array}$ & $\begin{array}{l}4.74 \\
\pm 0.99\end{array}$ & $\begin{array}{l}5.32 \\
\pm 0.39\end{array}$ & $\begin{array}{l}5.34 \\
\pm 1.02\end{array}$ & $\begin{array}{l}4.4 \\
\pm 1.16\end{array}$ & $\begin{array}{l}3.45 \\
\pm 0.59\end{array}$ & $\begin{array}{l}3.15 \\
\pm 1.07\end{array}$ & $\begin{array}{l}2.78 \\
\pm 0.24\end{array}$ & $\begin{array}{l}3.04 \\
\pm 0.22\end{array}$ & $\begin{array}{l}4.05 \\
\pm 0.50\end{array}$ & $\begin{array}{l}5.46 \\
\pm 1.32\end{array}$ & $\begin{array}{l}6.85 \\
\pm 1.09\end{array}$ & $\begin{array}{l}3.89 \\
\pm 0.54\end{array}$ & $\begin{array}{l}3.91 \\
\pm 0.24\end{array}$ \\
\hline $\begin{array}{l}\text { Area }\left(\mathrm{L}^{*} \mathrm{~W}\right) \\
\left(\mathrm{cm}^{2}\right)\end{array}$ & $\begin{array}{l}31.18 \\
\pm 8.89 \\
\end{array}$ & $\begin{array}{l}46.92 \\
\pm 8.56 \\
\end{array}$ & $\begin{array}{l}30.6 \\
\pm 12.87 \\
\end{array}$ & $\begin{array}{l}11.12 \\
\pm 1.43 \\
\end{array}$ & $\begin{array}{l}25.40 \\
\pm 5.76 \\
\end{array}$ & $\begin{array}{l}68.69 \\
\pm 21.75 \\
\end{array}$ & $\begin{array}{l}52.08 \\
\pm 7.12 \\
\end{array}$ & $\begin{array}{l}82.36 \\
\pm 18.79 \\
\end{array}$ & $\begin{array}{l}73.90 \\
\pm 22.74 \\
\end{array}$ & $\begin{array}{l}98.02 \\
\pm 8.92 \\
\end{array}$ & $\begin{array}{l}17.33 \\
\pm 4.64 \\
\end{array}$ & $\begin{array}{l}17.95 \\
\pm 8.95 \\
\end{array}$ & $\begin{array}{l}42.47 \\
\pm 11.65 \\
\end{array}$ & $\begin{array}{l}37.88 \\
\pm 18.06 \\
\end{array}$ & $\begin{array}{l}45.35 \\
\pm 7.52 \\
\end{array}$ & $\begin{array}{l}38.89 \\
\pm 4.89 \\
\end{array}$ & $\begin{array}{l}44.28 \\
\pm 15.73 \\
\end{array}$ & $\begin{array}{l}26.38 \\
\pm 9.1 \\
\end{array}$ & $\begin{array}{l}55.32 \\
\pm 17.69 \\
\end{array}$ & $\begin{array}{l}50.70 \\
\pm 18.18 \\
\end{array}$ & $\begin{array}{l}42.33 \\
\pm 4.87 \\
\end{array}$ \\
\hline & & & & & Group & & & Group 2 & & & Group & & & & & & & Group & & & \\
\hline
\end{tabular}




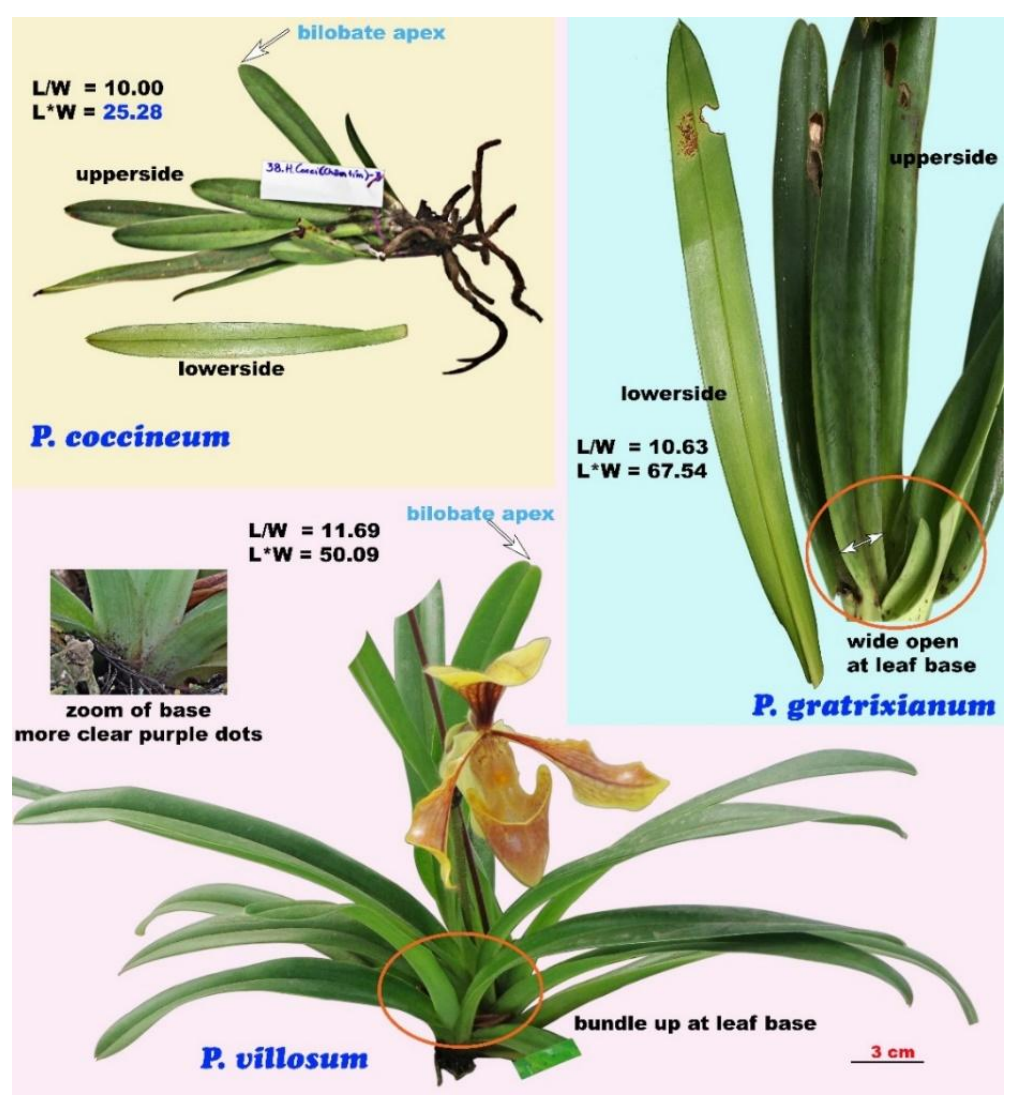

Fig. 4. Group 2 - P. coccianum, P. gratrixianum and P. villosum

The remained 6 species $P$. coccianum, $P$. dianthum, $P$. emersonii, $P$. gratrixianum, $P$. hangianum, and $P$. villosum were divided into two groups, which are significantly different in leaf length/width ratio. Group 2A composed of 3 species $P$. coccianum, $P$. gratrixianum, and $P$. villosum with length/width ratio more than 10 due to their long leaves (Fig. 4). Group 2B with big, large, hard, thick leaves and hence their leaf length/width ratio is just around $4.4-5.3$, including 3 species $P$. dianthum, $P$. hangianum and $P$. emersonii (Fig. 5) (Table 1). The size measurements were infered from our samples and from Khuat et al. [16].

Group 2A: There are less features to discriminate among 3 species $P$. coccianum, $P$. gratrixianum, and $P$. villosum, however, some detailed notions can be useful. $P$. coccianum has the smaller leaves than $P$. gratrixianum and $P$. villosum but these three species have long form leaf and their length/width are quite similar $(10.02 \pm 0.98,10.67 \pm 0.52$ and $11.36 \pm$ 3.10 correspondingly). The leaf area of $P$. coccianum is $25.40 \pm 5.76 \mathrm{~cm}^{2}$, while it is even more than $50 \mathrm{~cm}^{2}$ in $P$. gratrixianum and $P$. villosum (Table 1). The leaves of $P$. villosum grow straight up, are more slender and harder than $P$. gratrixianum (Fig. 4). The leaves of $P$. gratrixianum have larger broader lamina and tend to wide open at base, their purple marks are much blur against $P$. villosum (Fig. 4). This analysis may remind us of $P$. hirsutissimum with similar long form leaves. However this species has been previously identified by the purple marks at leaf base. Hence following the 
proposed order of distinguishing from this study is one of the key points for success of authentication of Vietnamese Paphiopedilum just based on vegetative morphology.

Group 2B: Finally we determined the species in group 2B with solid green, big, hard and large lamina including $P$. dianthum, $P$. hangianum and $P$. emersonii. Although in group of hard and thick leaves, $P$. dianthum leaves are particularly excessively hard and may reach $1.5-2 \mathrm{~mm}$ in thickness while it is only $0.3-1 \mathrm{~mm}$ in the two rests. Besides the angle between the leaves and the stem axis is about $30^{\circ}$ in $P$. dianthum while it is about $45^{\circ}-60^{\circ}$ in $P$. hangianum and

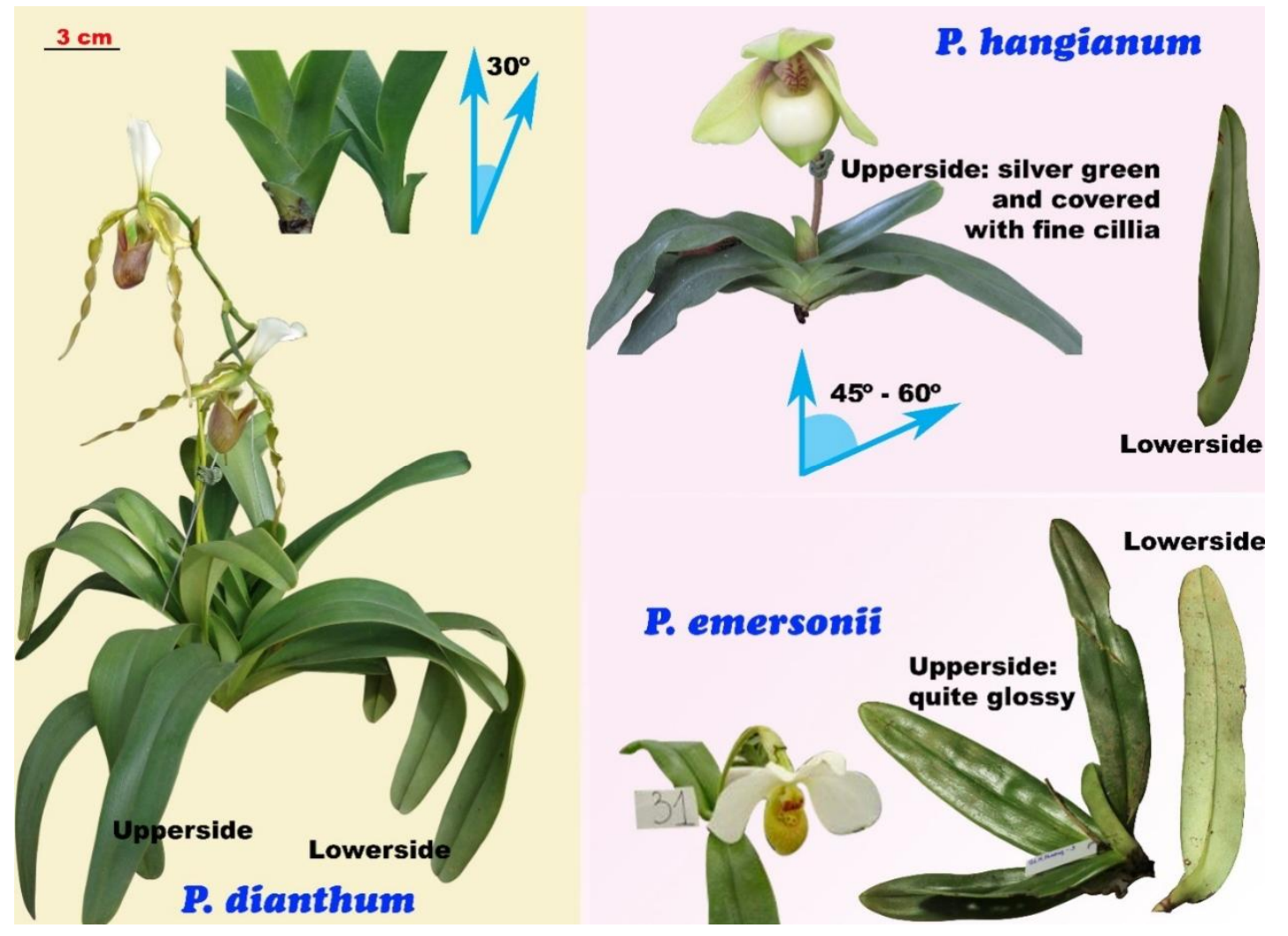

Fig. 5. Group $2-P$. dianthum, $P$. hangianum and $P$. emersonii

$P$. emersonii (Fig. 5). Thus $P$. dianthum leaves mostly raise straight up, bundle up the stem axis while $P$. hangianum and $P$. emersonii leaves open towards horizontal direction. There is not obvious distinction between $P$. hangianum and $P$. emersonii in vegetative morphology. $P$. hangianum leaves are silver green and covered with fine cilia which look like a dusty layer. $P$. emersonii leaves has blur veins and quite glossy (Fig. 5).

\subsubsection{Artificial key based on leaf morphology to the genus Paphiopedilum}

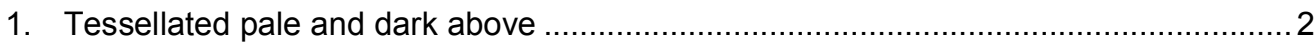

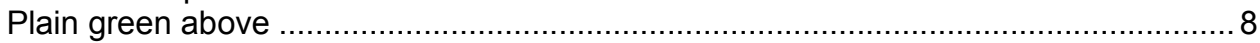

2. Purple or red purple marks most of the surface below ........................................ 3

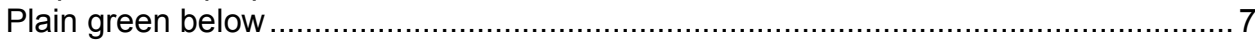

3. Linear veins causing polygonal mottles above.................................................... 4 Curve veins causing round; less clearly mottles above; look like mottles on the panther feather

4. Glossy surfaces; thick; silver green .................................. Paphiopedilum vietnamense Rough surfaces 
Slightly rough, no glossy surfaces.

5. Pale silver green, small purple dots distributing sparsely below

Larger and much more purple marks below

. Paphiopedilum malipoense var. jackii

Paphiopedilum malipoense var. malipoense

6. Length/width rate about 2.7 ; wide, thin, softer, slightly plicate; tessellated marks make up equal or less than $50 \%$ the pale green background; longitudinal veins not even and tight causing polygonal mottles; acute tip ..........................Paphiopedilum delenatii Length/width rate about 3.5; long form leaf; tessellated marks make up more than $50 \%$ the pale green background; evenly rectangular mottles, obtuse tip

Paphiopedilum armeniacum, Paphiopedilum micranthum

7. Green background, fainted veins, horizontal serrated veins look like pattern of waterfall on glass Paphiopedilum dalatense Light green background make up more than dark green mottles; clearly parallele veins; sparsely rectangular tessellates Paphiopedilum appletonianum Dark green mottles make up more than light green background; fainted veins.

Paphiopedilum callosum, Paphiopedilum purpuratum

8. Light and thin white/yellow line at leaf margin

Clear and bold white line at leaf margin

Paphiopedilum henryanum

9. Purple spots at base below .....

No purple marks at base below......

Paphiopedilum hirsutissimum

Purple streaks at base below, the lamina towards the base is wide, turn over

outer instead of bundling up the stem

Paphiopedilum tranlienianum

10. Extremely short; leaves $7-9 \mathrm{~cm}$ long; $1.2-1.4$ wide; leaf area $\Sigma 11 \mathrm{~cm}^{2}$; length/width ratio $\Sigma 6$ Paphiopedilum helenae

Length/width ratio more than 10; long, thin leaves

Length/width ratio $4.4-5.3$, large, hard, thick leaves

11. Leaf area $26 \mathrm{~cm}^{2}$ Leaf area $60-70 \mathrm{~cm}^{2}$.

Paphiopedilum coccineum

12. Leaf grows straight up, more slender and harder, clear purple marks below Paphiopedilum villosum

Leaf has larger broader lamina and tend to wide open at base, blur purple marks below Paphiopedilum gratrixianum

13. Leaves extremely hard; thickness $1.5-2 \mathrm{~mm}$; plain or slightly plicate; angle between leaves and stem axis about $30^{\circ}$ Paphiopedilum dianthum Thickness $0.5-1 \mathrm{~mm}$; angle between leaves and stem axis more than $45^{\circ}-60^{\circ}$ Paphiopedilum hangianum, Paphiopedilum emersonii

\subsubsection{Combination of vegetative morphological and molecular methods in identification of Vietnamese Paphiopedilum species}

In our previous study, nucleotide polymorphism and phylogenetic tree based on DNA sequences of these Vietnamese Paphiopedilum orchids were also analyzed. Sixteen species have been clearly identified using ITS + matK region [15]. For combination of both molecular and leaf morphological methods, all of the studied species were separated completely in this study (Table 2). Two variants of $P$. malipoense were also well identified.

Discrimination and identification of species are basis for conservation, development or breeding of valuable genetic resources $[1,17]$. Various identification methods have been developed, of which morphological and molecular techniques are common used. Guo et al. (2016) conducted a research on identification of 77 Paphiopedilum species using DNA sequences of rpoC2, atpF$a t p \mathrm{H}, y c f 1$, atpl-atpH, accD, trnS-trnfM, $r b c \mathrm{~L}$ and ITS as DNA barcodes. This method, however could still not resolve $100 \%$ of studied species [18]. Two species Paphiopedilum gratrixianum and $P$. villosum, which were unseparated by that barcoding study, were clearly identified in our research based on leaf characters. Our study shown that the use of morphology can effectively support species resolution.

Despite being considered a long-standing and traditional method, morphological analysis has been widely applied so far because of its 
usability. Various morphological characteristics were used as classification criteria for orchids such as roots [19], pseudobulbs [17], fruits [20], especially flower organs $[4,6]$. Some identification researches based on the combination of morphology and other techniques $[21,22]$. Research based only on vegetative morphology was hardly found so far.

There were different approaches of morphological description due to different purposes. Some studies described morphology features corresponding to the functions in their environments $[4,19]$. In the study of Sandal et al. (2018) and Hartati et al. (2019), different morphological traits of leaf, stem, body, spike, and flowers were compared at the same time for similarity. Character matrices were established for inferring phylogenetic trees and the relationships between taxa were discussed [17, 21]. On the other hand, Cribb and Whistler (2011) developed an artificial key to identify genera of Orchidaceae in Tonga. All features of organs such as stem, tuber, flower organs, pseudobulbs, leaves, roots and even environmental traits (epiphytic, lithophytic) were analyzed [9]. In our study, artificial key for 20 Paphiopedilum species of Vietnam were also established which did not show the differences or similarities between taxa, but described leaf traits in an order manner so that readers can easily lookup for species identification.

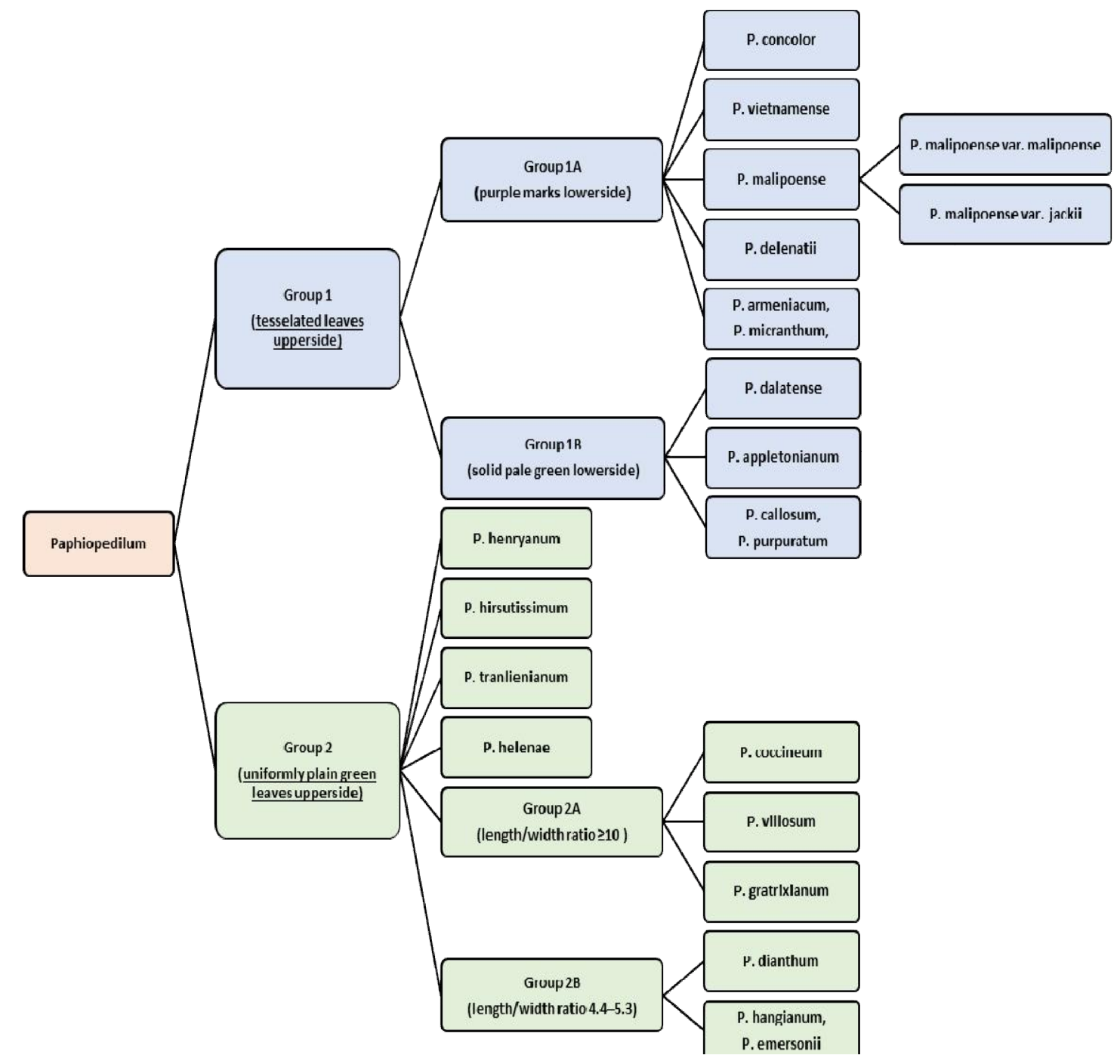

Fig. 6. Dendrogram of summarized process of identification of Paphiopedilum species in Vietnam 
Table 2. Number of distinguished species based on molecular and morrpholigical methods separately and in combination

\begin{tabular}{|c|c|c|c|c|}
\hline No. & Paphiopedilum species & $\begin{array}{l}\text { Distinguished } \\
\text { species based } \\
\text { on molecular } \\
\text { method }\end{array}$ & $\begin{array}{l}\text { Distinguished species } \\
\text { based on vegetative } \\
\text { morphological method }\end{array}$ & $\begin{array}{l}\text { Distinguished } \\
\text { species based on } \\
\text { two-method } \\
\text { combination }\end{array}$ \\
\hline 1 & P. appletonianum & + & + & + \\
\hline 2 & P. armeniacum & + & - & + \\
\hline 3 & P. callosum & + & - & + \\
\hline 4 & P. coccineum & + & + & + \\
\hline 5 & P. concolor & + & + & + \\
\hline 6 & P. dalatense & + & + & + \\
\hline 7 & P. delenatii & + & + & + \\
\hline 8 & P. dianthum & + & + & + \\
\hline 9 & P. emersonii & + & - & + \\
\hline 10 & P. gratrixianum & - & + & + \\
\hline 11 & $P$. hangianum & + & - & + \\
\hline 12 & $P$. helenea & + & + & + \\
\hline 13 & P. henryanum & - & + & + \\
\hline 14 & P. hirsutissimum & + & + & + \\
\hline $15 a$ & P. malipoense var. malipoense & + & + & + \\
\hline $15 b$ & P. malipoense var. jackii & & + & + \\
\hline 16 & P. micranthum & + & - & + \\
\hline 17 & P. purpuratum & + & - & + \\
\hline 18 & P. tranlienianum & - & + & + \\
\hline 19 & $P$. vietnamense & + & + & + \\
\hline 20 & P. villosum & - & + & + \\
\hline \multicolumn{2}{|c|}{ Number of distinguished species } & $16 / 20$ & $14 / 20$ & $20 / 20$ \\
\hline
\end{tabular}

\section{CONCLUSIONS}

For practical identification of Paphiopedilum species, leaf morphology can be effectively used as the first step following by molecular process for unidentified species. This strategy can help to reduce the time and cost in biodiversity control and national resource conservation assignment. This study discovered the leaf features that can be beneficial for quick and easy identification of Paphiopedilum species in Vietnam. This study will help the researchers to uncover the critical areas of vegetative morphology that many researchers did not mentioned. A new theory on artificial key may provide practical use in trading control of endangered Paphiopedilum species.

\section{ACKNOWLEDGEMENTS}

The authors thank to Tay Nguyen Institute for Scientific Research and Agricultural Genetics Institute, Vietnam and Mr. Hong Son Le for providing Paphiopedilum samples for this study. This study is partial funded by Department of Science and Technology of Ho Chi Minh City, Vietnam, project number 312/2013/HD-SKHCN.

\section{COMPETING INTERESTS}

Authors have declared that no competing interests exist.

\section{REFERENCES}

1. Kasutjianingati K, Firgiyanto R. Characterization of morphology from orchid Vanda sp. as a genetic information source for preservation and agribusiness of orchids in Indonesia. IOP Conference Series: Earth and Environmental Science. 2018; 207:012006.

2. Burns-Balogh $P$, Hesse M. Pollen morphology of the cypripedioid orchids. Plant Systematics and Evolution. 1988; 158(2/4):165-182.

3. Dirks A, Ahmed I, Broek M, Krol L, Menger N, Snier J, Winzum A, Wolf A, Wout M, Zeegers J, Butôt R, Heijungs R, Heuven B, Kruizinga J, Langelaan R, Smets E, Star W, Bemer M, Gravendeel B. Morphological and molecular character-ization of orchid fruit development. Frontiers in Plant Science. 2019;10.

4. Singer RB, Sazima M. Flower Morphology and pollination mechanism in three sympatric goodyerinae orchids from Southeastern Brazil. Annals of Botany. 2001;88(6):989-997.

5. Einzmann H, Schickenberg N, Zotz G. Variation in root morphology of epiphytic orchids along small-scale and large-scale 
moisture gradients. Acta Botanica Brasilica; 2019.

6. Tsiftsis S. Morphological variability of Himantoglossum s.s. (Orchidaceae) in Greece. Phytotaxa. 2016;245:17-30.

7. De L, Singh DR, Singh R. Morphological characterization in Mokara Orchids; 2019.

8. Zhang FP, Huang JL, Zhang SB. Trait evolution in the slipper orchid Paphiopedilum (Orchidaceae) in China. Plant Signaling \& Behavior. 2016;11(3): e1149668.

9. Cribb $\mathrm{P}$, Whistler $\mathrm{A}$. The orchids of Tonga, Niue and the Cook Islands. Lankesteriana. 2011;11.

10. Tran H. The orchids of Vietnam. Agriculture: Hochiminh City; 2000.

11. Averyanov L, Cribb $\mathrm{P}$, Phan $\mathrm{KL}$, Nguyen $\mathrm{TH}$. Slipper orchids of Vietnam. Bird life, Royal Botanic Gardens KEW, World Bank: Ho Chi Minh City; 2004.

12. Cribb P, The Genus Paphiopedilum. $2^{\text {nd }}$ ed. Natural History Publications (Borneo); 1998.

13. Cribb P. The genus Paphiopedilum: A kew magaine monograph. The Royal Botanic Gardens, Kew/Timber Press; 1987.

14. Zhongjian L, Xinqi C, Cribb PJ, Flora of China. Orchidaceae. Missouri Botanical Garden Press. 2009;25.

15. Vu HT, Nguyen TD, Tran HD, Vu QL, Tran $\mathrm{N}$, Nguyen TC, Luu PN, Tran DD, Nguyen TK, Le L. Identification of vietnamese Paphiopedilum species using DNA sequences. Biology.

16. Khuat HT, Tran DK, Le HH, Tran DD, Nguyen TK. Evaluation of genetic diversity
Paphiopedilum groups in morphology; analysis of specific characteristic of indigenous gene resource of Paphiopedilum in Vietnam. Ministry of Science and Technology: Hanoi, Vietnam; 2008.

17. Hartati S, Muliawati E, Pardono $P$, Cahyono O, Yuliyanto P. Morphological characterization of Coelogyne spp for germplasm conservation of orchids. Revista Ceres. 2019;66:265-270.

18. Guo $Y Y$, Huang LQ, Liu ZJ, Wang $X Q$. Promise and Challenge of DNA Barcoding in Venus Slipper (Paphiopedilum). PLOS One. 2016;11(1):e0146880.

19. Einzmann HJR, Schickenberg N, Zotz G. Variation in root morphology of epiphytic orchids along small-scale and large-scale moisture gradients. Acta Botanica Brasilica; 2019.

20. Dirks-Mulder A, Ahmed I, Broek Muh, Krol L, Menger N, Snier J, Winzum Av, Wolf Ad, Wout Mvt, Zeegers JJ, Butôt R, Heijungs R, Heuven BJV, Kruizinga J, Langelaan R, Smets EF, Star W, Bemer M, Gravendeel B. Morphological and Molecular Characterization of Orchid Fruit Development. Frontiers in Plant Science. 2019;10.

21. Sandal Erzurumlu G, Sultana N, Vural M, Serce S. Genetic and phenotypic variation among Turkish terrestrial orchid species as revealed by RAPD and morphological characteristics. Turkish Journal of Agriculture and Forestry. 2018;42.

22. Dathe $\mathrm{S}$, Dietrich $\mathrm{H}$. Comparative molecular and morphological studies in selected Maxillariinae orchids. Willdenowia. 2006;36.

(0) $2019 \mathrm{Vu}$ et al.; This is an Open Access article distributed under the terms of the Creative Commons Attribution License (http://creativecommons.org/licenses/by/4.0), which permits unrestricted use, distribution, and reproduction in any medium, provided the original work is properly cited.

Peer-review history:

The peer review history for this paper can be accessed here: http://www.sdiarticle4.com/review-history/53724 